OPEN ACCESS

Edited by:

Gordon T. Taylor,

Stony Brook University, USA

Reviewed by:

Hugh Daigle,

University of Texas at Austin, USA

Luni Sun,

Old Dominion University, USA

*Correspondence:

Leanne C. Powers

leanne.powers@gmail.com

${ }^{\dagger}$ Present Address:

Leanne C. Powers,

Chesapeake Biological Laboratory,

University of Maryland Center for

Environmental Science, Solomons,

MD, USA

Specialty section:

This article was submitted to Marine Biogeochemistry,

a section of the journal

Frontiers in Marine Science

Received: 20 August 2016 Accepted: 01 November 2016 Published: 18 November 2016

Citation:

Powers LC and Miller WL (2016) Apparent Quantum Efficiency Spectra for Superoxide Photoproduction and Its Formation of Hydrogen Peroxide in Natural Waters. Front. Mar. Sci. 3:235. doi: 10.3389/fmars.2016.00235

\section{Apparent Quantum Efficiency Spectra for Superoxide Photoproduction and Its Formation of Hydrogen Peroxide in Natural Waters}

\author{
Leanne C. Powers ${ }^{1 * t}$ and William L. Miller ${ }^{2}$ \\ ${ }^{1}$ Department of Marine Science, Skidaway Institute of Oceanography, University of Georgia, Savannah, GA, USA, \\ ${ }^{2}$ Department of Marine Science, University of Georgia, Athens, GA, USA
}

Superoxide $\left(\mathrm{O}_{2}^{-}\right)$is a key intermediate in the cycling of organic matter and trace metals in natural waters but production rates are difficult to determine due to low steady-state concentrations, rapid decay rates, and unstable standards. On the other hand, superoxide's dismutation product, hydrogen peroxide $\left(\mathrm{H}_{2} \mathrm{O}_{2}\right)$, is relatively stable in filtered water. Thus, if the stoichiometry between $\mathrm{O}_{2}^{-}$and $\mathrm{H}_{2} \mathrm{O}_{2}$ is known, one can derive superoxide data from $\mathrm{H}_{2} \mathrm{O}_{2}$ measurements. The relationship between $\mathrm{O}_{2}^{-}$and $\mathrm{H}_{2} \mathrm{O}_{2}$ remains uncertain in seawater but work by Petasne and Zika (1987) presented a method for examining the relationship between $\mathrm{O}_{2}^{-}$and $\mathrm{H}_{2} \mathrm{O}_{2}$ during irradiations of coastal seawater using superoxide dismutase (SOD), which forces a 2:1 stoichiometry between $\mathrm{O}_{2}^{-}$and $\mathrm{H}_{2} \mathrm{O}_{2}$. Here we report the first $\mathrm{O}_{2}^{-}$apparent quantum yield (AQY) spectra following their approach; performing irradiations of various fresh and seawater samples and measuring $\mathrm{H}_{2} \mathrm{O}_{2}$ accumulation with and without added SOD. For all but a single riverine sample, $\mathrm{H}_{2} \mathrm{O}_{2}$ AQY spectra fell in a narrow range, but $\mathrm{O}_{2}^{-}$AQY spectra varied such that $\mathrm{O}_{2}^{-}: \mathrm{H}_{2} \mathrm{O}_{2}$ ratios were always $>2$ and were highest for the clear waters of the Gulf Stream $\left(\sim 3.4 \mathrm{O}_{2}^{-}\right.$per $\mathrm{H}_{2} \mathrm{O}_{2}$ generated). Because this approach eliminates the need to measure $\mathrm{O}_{2}^{-}$production rates directly, it represents a simple way to refine the stoichiometric relationships that would potentially allow global estimates of $\mathrm{O}_{2}^{-}$photoproduction rates, $\mathrm{O}_{2}^{-}$steady-state concentrations $\left(\left[\mathrm{O}_{2}^{-}\right]_{\mathrm{ss}}\right)$, and related surface ocean redox reactions based on more manageable $\mathrm{H}_{2} \mathrm{O}_{2}$ photochemical studies.

Keywords: photochemistry, hydrogen peroxide, superoxide, superoxide dismutase, apparent quantum yield

\section{INTRODUCTION}

It is well-known that hydrogen peroxide $\left(\mathrm{H}_{2} \mathrm{O}_{2}\right)$ in natural waters largely results from thermal reactions involving superoxide $\left(\mathrm{O}_{2}^{-}\right)$(Kieber et al., 2003). Ever since Bielski and coworkers (Bielski and Allen, 1977; Bielski, 1978; Bielski et al., 1985) reported rate constants for many superoxide reactions in aqueous solutions, it has long been assumed that the $\mathrm{H}_{2} \mathrm{O}_{2}$ in seawater primarily results from $\mathrm{O}_{2}^{-}$disproportionation, giving a stoichiometry of two $\mathrm{O}_{2}^{-}$consumed for each $\mathrm{H}_{2} \mathrm{O}_{2}$ generated (Bielski et al., 1985). Zafiriou et al. (1990) subsequently published the first $\mathrm{pH}$-dependent $\mathrm{O}_{2}^{-}$dismutation decay constant in seawater $\left(k_{\mathrm{D}} ; \mathrm{M}^{-1} \mathrm{~s}^{-1}\right)$, which agreed well with that reported for pure water by Bielski et al. (1985). Additionally, $\mathrm{H}_{2} \mathrm{O}_{2}$ photochemical production is temperature 
dependent (Szymczak and Waite, 1988; Kieber et al., 2014), providing further evidence for a dominant role for a thermal reaction such as $\mathrm{O}_{2}^{-}$dismutation in $\mathrm{H}_{2} \mathrm{O}_{2}$ production. In $0.2 \mu \mathrm{m}$ filtered seawater, $\mathrm{H}_{2} \mathrm{O}_{2}$ is relatively stable (Cooper et al., 1989) relative to its precursor, $\mathrm{O}_{2}^{-}$, making $\mathrm{H}_{2} \mathrm{O}_{2}$ much easier to quantify. Thus, studies have often inferred $\mathrm{O}_{2}^{-}$formation rates by measuring $\mathrm{H}_{2} \mathrm{O}_{2}$ formation rates, primarily in photochemical exposures of colored dissolved organic matter (CDOM), and assuming a $2 \mathrm{O}_{2}^{-}: 1 \mathrm{H}_{2} \mathrm{O}_{2}$ stoichiometry between the two species (e.g., Powers and Miller, 2014).

Because $\mathrm{O}_{2}^{-}$acts as both an oxidant and a reductant, it is a key intermediate in the cycling of trace metals and organic matter in natural waters (Kieber et al., 2003; Rose and Waite, 2006; Wuttig et al., 2013). As more work has been done investigating superoxide dynamics over the past several decades, it is clear that dismutation is not always the dominant fate of $\mathrm{O}_{2}^{-}$decay in natural waters. In fact, dominant routes can include reactions with iron, manganese, copper or CDOM (e.g., Voelker et al., 2000; Heller and Croot, 2010a,b; Wuttig et al., 2013) depending on the system. However, redox cycling of trace metals or CDOM can also result in the 2:1 stoichiometry typical of dismutation, and consequently a 2:1 stoichiometry should not always be assumed to reflect the dismutation of $\mathrm{O}_{2}^{-}$. Petasne and Zika (1987) were the first to report that a large fraction (24-41\%) of $\mathrm{O}_{2}^{-}$photoproduction does not lead to its dismutation product $\mathrm{H}_{2} \mathrm{O}_{2}$ based on irradiations of coastal seawater with and without additions of the enzyme superoxide dismutase (SOD). SOD forces a 2:1 stoichiometry between $\mathrm{O}_{2}^{-}$and $\mathrm{H}_{2} \mathrm{O}_{2}$ with a rate constant of $>10^{9} \mathrm{M}^{-1} \mathrm{~s}^{-1}$ (Cudd and Fridovich, 1982), which is more than 4 orders of magnitude larger than $k_{\mathrm{D}}$ at the $\mathrm{pH}$ of seawater. Thus, monitoring the difference between $\mathrm{H}_{2} \mathrm{O}_{2}$ photoproduction in the presence and absence of SOD should provide insight into the pathways for $\mathrm{O}_{2}^{-}$loss. Furthermore, Garg et al. (2011) found that additions of SOD increased the concentrations of photoproduced $\mathrm{H}_{2} \mathrm{O}_{2}$ during irradiations of Suwannee River Fulvic Acid (SRFA) solutions and more recently Zhang and Blough (2016) found that the photoproduction rates of one-electron reducing intermediates (i.e., the precursor for $\mathrm{O}_{2}^{-}$; Zhang et al., 2012) were 6-13 times greater than those for $\mathrm{H}_{2} \mathrm{O}_{2}$ in similar solutions of SRFA and other standard materials. In natural waters, Rusak et al. (2011) observed a ratio of 0.37 $\mathrm{H}_{2} \mathrm{O}_{2}$ per $\mathrm{O}_{2}^{-}$consumed but used unfiltered samples that are not reflective of solely photochemical production and abiotic decay. Powers et al. (2015) measured photochemical production of $\mathrm{H}_{2} \mathrm{O}_{2}$ and $\mathrm{O}_{2}^{-}$together via chemiluminescent detection, resulting in a stoichiometry between $\mathrm{O}_{2}^{-}$and $\mathrm{H}_{2} \mathrm{O}_{2}$ closer to $4: 1$ in seawater collected in the Gulf of Alaska.

It is clear that in order to fully understand the role of $\mathrm{O}_{2}^{-}$in marine biogeochemical cycling its production and decay must be modeled on global scales. We presented one such method to assess the photochemical production of both superoxide and hydrogen peroxide in early 2014 (Powers and Miller, 2014) by blending UV optics derived from remotely sensed ocean color data, modeled solar irradiances and $\mathrm{H}_{2} \mathrm{O}_{2}$ apparent quantum yield (AQY) spectra to generate monthly climatologies for both $\mathrm{H}_{2} \mathrm{O}_{2}$ and $\mathrm{O}_{2}^{-}$in open ocean seawater. The approach was novel as presented, but had several shortcomings. These included the method for determination of hydrogen peroxide AQY spectra, which describe the efficiency of its production as moles product produced divided by the moles photons absorbed by CDOM. An assumption of all AQY calculations based on a single time point measurement is that the product is generated as a linear function of photon dose. With these experiments, as done in Powers and Miller (2014), it is unclear whether this requirement is met, especially when a lack of reciprocity for $\mathrm{H}_{2} \mathrm{O}_{2}$ photoproduction over irradiation time has been reported elsewhere (Kieber et al., 2014; Powers et al., 2015). Results of SOD addition experiments were also variable in this study, so a 2:1 stoichiometry between $\mathrm{O}_{2}^{-}$and $\mathrm{H}_{2} \mathrm{O}_{2}$ was assumed and $\mathrm{O}_{2}^{-}$photoproduction rates were predicted using this stoichiometry together with the AQY for $\mathrm{H}_{2} \mathrm{O}_{2}$. To date, no direct $\mathrm{O}_{2}^{-}$AQY spectra have been published.

As the 30th anniversary of the Petasne and Zika (1987) study approaches, we have re-evaluated the portioning between $\mathrm{O}_{2}^{-}$and $\mathrm{H}_{2} \mathrm{O}_{2}$ and determined the first $\mathrm{O}_{2}^{-}$AQY spectra following their approach: irradiation of seawater samples and measurements of $\mathrm{H}_{2} \mathrm{O}_{2}$ production with and without added SOD. Because this method eliminates the need to measure $\mathrm{O}_{2}^{-}$production rates directly, it may therefore be a simple way to refine estimates of $\mathrm{O}_{2}^{-}$photoproduction rates and $\mathrm{O}_{2}^{-}$steady-state concentrations $\left(\left[\mathrm{O}_{2}^{-}\right]_{\text {ss }}\right)$ in the ocean.

\section{METHODS}

\section{Sample Collection and Handling}

Surface seawater samples $(\sim 5 \mathrm{~m})$ were collected in the South Atlantic Bight (SAB) off the coast of Georgia (GA), USA onboard the R/V Savannah in June 4-6, 2016 and locally off the Skidaway River Estuary (SRE) dock (July 20, 2016) and the Altamaha River (August 5, 2016) (Table 1). All sampling equipment (tubing, filters and containers) were acid-cleaned (overnight in $0.01 \mathrm{M}$ $\mathrm{HCl}$ ), Milli-Q water (Millipore; $>18 \mathrm{M} \Omega$ ) rinsed (5 times), and dried prior to sampling. Samples were filtered either directly from Niskin bottles or pumped through $0.2 \mu \mathrm{m}$ filters (Whatman; Polycap-75AS) into 10 or $20 \mathrm{~L}$ acid-cleaned polyethylene carboys (Nalgene) and stored at $4^{\circ} \mathrm{C}$ until use, for a period of up to 1 month. Our experience indicates that storage for seawater samples does not impact sample optics or the photochemical production rates for $\mathrm{H}_{2} \mathrm{O}_{2}$ (Powers et al., 2015). While all equipment in contact with seawater samples was acid cleaned as described above and nitrile gloves were used in handling samples, the R/V Savannah and the laboratory was not equipped with special trace metal processing facilities and thus, limited trace metal contamination could be present.

\section{Hydrogen Peroxide Analysis}

$\mathrm{H}_{2} \mathrm{O}_{2}$ was measured using a FeLume chemiluminescence (CL) system (Waterville Analytical) and modifications to the methods of King et al. (2007). Briefly, samples were mixed with $2 \mu \mathrm{M}$ 10-methyl-9-( $p$-formylphenyl)-acridinium carboxylate trifluoromethanesulfonate (AE; provided by Dr. James J. Kiddle, Western Michigan University), which reacts with $\mathrm{H}_{2} \mathrm{O}_{2}$ to chemiluminesce at alkaline $\mathrm{pH}$. A syringe was used to flush $(\geq 1 \mathrm{~mL}$ ) and fill a $195 \mu \mathrm{L}$ Teflon sample loop (VICI 10-port valve) that was subsequently mixed with the AE reagent using 


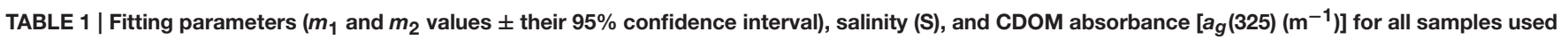
in $A Q Y$ determinations.

\begin{tabular}{|c|c|c|c|c|c|c|c|}
\hline \multicolumn{8}{|c|}{ (A) $\mathrm{H}_{2} \mathrm{O}_{2}$ AQY SPECTRA } \\
\hline Sample & $S$ & $a_{g}(325)\left(m^{-1}\right)$ & Treatment & $m_{1}$ & $m_{2}$ & $r^{2}$ & nRMSE (\%) \\
\hline \multirow[t]{2}{*}{ Altamaha R. } & 0 & 13.6 & none & $6.68 \pm 0.43$ & $0.0228 \pm 0.0077$ & 0.95 & 7.8 \\
\hline & & & SOD & $6.12 \pm 0.40$ & $0.0369 \pm 0.0092$ & 0.95 & 7.1 \\
\hline SRE A & 31 & 6.11 & none & $7.79 \pm 0.29$ & $0.0229 \pm 0.0061$ & 0.99 & 3.6 \\
\hline \multirow[t]{2}{*}{ SRE B } & 31 & 6.38 & none & $7.73 \pm 0.55$ & $0.0265 \pm 0.0123$ & 0.95 & 7.8 \\
\hline & & & SOD & $7.27 \pm 0.44$ & $0.0305 \pm 0.0106$ & 0.97 & 5.4 \\
\hline \multirow[t]{2}{*}{ Midshelf } & 34 & 1.41 & none & $7.52 \pm 0.45$ & $0.0243 \pm 0.0110$ & 0.98 & 4.9 \\
\hline & & & SOD & $6.89 \pm 0.46$ & $0.0368 \pm 0.0143$ & 0.98 & 5.2 \\
\hline \multirow[t]{2}{*}{ Gulf Stream } & 37 & 0.237 & none & $7.91 \pm 0.73$ & $0.0225 \pm 0.0120$ & 0.91 & 9.2 \\
\hline & & & SOD & $6.80 \pm 0.53$ & $0.0425 \pm 0.0149$ & 0.95 & 7.6 \\
\hline \multicolumn{8}{|c|}{ (B) $\mathrm{O}_{2}^{-}$AQY SPECTRA } \\
\hline Sample & & & & $m_{1}$ & $m_{2}$ & $r^{2}$ & nRMSE (\%) \\
\hline Altamaha R. & & & & $5.42 \pm 0.40$ & $0.0369 \pm 0.0091$ & 0.95 & 7.1 \\
\hline SRE B & & & & $6.58 \pm 0.44$ & $0.0305 \pm 0.0106$ & 0.97 & 5.4 \\
\hline Midshelf & & & & $6.20 \pm 0.46$ & $0.0368 \pm 0.0143$ & 0.98 & 5.2 \\
\hline Gulf Stream & & & & $6.11 \pm 0.53$ & $0.0425 \pm 0.0148$ & 0.95 & 7.6 \\
\hline
\end{tabular}

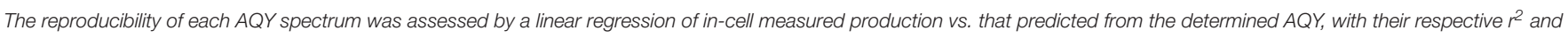
normalized root mean square error (nRMSE).

a peristaltic pump (Rainin). The sample/carrier-AE mix was transported to a spiral flow cell (Global FIA) located in front of a photomultiplier tube (PMT; Hamamatsu HC135 PMT, 900 $\mathrm{V}, 400 \mathrm{~ms}$ integration) where it mixed with $0.1 \mathrm{M}$ carbonate buffer to initiate CL. Decreased carbonate buffer $\mathrm{pH}$ (10.4) using $0.2 \mathrm{M} \mathrm{HCl}$ as the carrier prevented interference by precipitated $\mathrm{Mg}(\mathrm{OH})_{2}$ and helped decrease background CL. A $\sim 2 \mathrm{mM} \mathrm{H}_{2} \mathrm{O}_{2}$ stock solution was prepared from $30 \% \mathrm{H}_{2} \mathrm{O}_{2}$ (J. T. Baker) and measured weekly for stability using its absorbance (molar absorptivity $38.1 \mathrm{M}^{-1} \mathrm{~cm}^{-1}$ at $240 \mathrm{~nm}$; Miller and Kester, 1988) on a single beam UV-Vis spectrophotometer (Agilent) with Milli-Q as the absorbance blank. Standards were prepared in seawater samples matching those used in irradiations and were checked for low or undetectable $\mathrm{H}_{2} \mathrm{O}_{2}$ starting values against the same seawater with added catalase $\left(20 \mu \mathrm{L}\right.$ of 100 units $\mathrm{L}^{-1}$ in $20 \mathrm{~mL}$ seawater; C100 Sigma-Aldrich). Under these conditions, the $\mathrm{H}_{2} \mathrm{O}_{2}$ detection limit, defined as three times the standard deviation of the blank, was $2 \mathrm{nM}$.

\section{Photochemical Irradiations and Apparent Quantum Yield (AQY) Determination}

Prior to irradiation experiments, each seawater sample was brought to room temperature and refiltered through a $0.2 \mu \mathrm{m}$ membrane filter (described above) and portioned into two acidclean and combusted $\left(450^{\circ} \mathrm{C}\right.$ for $\left.5 \mathrm{~h}\right) 1 \mathrm{~L}$ borosilicate bottles (Kimax). For each sample, one bottle was left unamended and the other was treated with an addition of the enzyme superoxide dismutase (SOD; S7571-15KU, Sigma) immediately prior to irradiation. SOD was stored at $-20^{\circ} \mathrm{C}$ when not in use, and a fresh stock solution of $\sim 1.5 \times 10^{7} \mathrm{U} \mathrm{L}^{-1} \mathrm{SOD}$ (calculated from the manufacturer's reported activity) was prepared in Milli-Q and stored at $4{ }^{\circ} \mathrm{C}$ for a period of up to 2 weeks. SOD activity was verified by monitoring $\mathrm{O}_{2}^{-}$photoproduction in the absence of SOD and subsequently observing no $\mathrm{O}_{2}^{-}$production in the presence of added SOD, using methods for superoxide described previously (Powers et al., 2015). $1.5 \times 10^{4}$ Units L $^{-1}$ SOD (based on the manufacturer's assay) was used for all 15-min irradiation experiments with added SOD.

All irradiations were performed using a Suntest CPS solar simulator equipped with a $1.5 \mathrm{~kW}$ xenon lamp (Atlas). For time series and initial rate determinations, the solar simulator was fitted with a window glass filter to simulate sunlight reaching the earth's surface ( $\sim 295 \mathrm{~nm}$ and above). All samples were distributed into 15 matched $10 \mathrm{~cm}$ cylindrical quartz spectrophotometric cells, filled leaving no headspace, and sealed using gas-tight caps fitted with Teflon-faced, butyl rubber septa. Cells were placed vertically below the solar simulator into a black, water-cooled, aluminum irradiation block fitted with a one inch gray PVC lid with $1.6 \mathrm{~cm}$ diameter apertures directly above the cell windows to eliminate residual off-axis photons. The $\mathrm{Al}$ block maintained the samples at $20^{\circ} \mathrm{C}$ and allowed no transfer of light between cells during irradiation. For $\mathrm{H}_{2} \mathrm{O}_{2}$ AQY determination, wavelength dependent experiments were also performed by removing the window glass filter and aligning the block, and therefore each cell, under a variety of evenly spaced Schott long-band-pass filters $(280,295,305,320,380,425$, and $480 \mathrm{~nm} \mathrm{50 \%} \mathrm{cutoff).} \mathrm{One} \mathrm{dark} \mathrm{control} \mathrm{was} \mathrm{kept} \mathrm{in} \mathrm{the} \mathrm{same}$ irradiation block as other samples but with all irradiance blocked. Additional dark control sample cells were kept covered in the water bath. The spectral downwelling irradiance entering each 
cell, $E_{0}(\lambda)\left[\mathrm{mol}\right.$ (photons) $\mathrm{m}^{-2} \mathrm{~s}^{-1} \mathrm{~nm}^{-1}$, was quantified at $1 \mathrm{~nm}$ intervals with a UV-Vis portable spectroradiometer (OL756; Optronic Laboratories) fitted with a quartz fiber optic cable and $2^{\prime \prime}$ diameter integrating sphere. The OL756 was calibrated with a NIST standard lamp (OL752-10 irradiance standard; Optronic Laboratories).

Accurate and precise measurements of CDOM absorbance (A) are critical in determining the photons absorbed in these irradiation experiments. Absorbance spectra from 250 to $800 \mathrm{~nm}$ were measured using an UltraPath liquid waveguide cell (World Precision Instruments; Miller et al., 2002) for the clear Gulf Stream sample, with a high powered UV-Vis light source (Hamamatsu) and a fiber optic assembly attached to a MAYA2000-Pro UV-Vis spectrometer (Ocean Optics). The liquid waveguide cell of the UltraPath provides a $2 \mathrm{~m}$ pathlength, with absorbance sensitivity 20 times greater than standard spectrophotometers holding $10 \mathrm{~cm}$ cuvettes. Blanks, cleaning protocols, and refractive index corrections for salinity changes were performed as in Stubbins et al. (2006). For all samples, absorbance in each $10 \mathrm{~cm}$ irradiation cell was also measured from 190 to $1100 \mathrm{~nm}$ with a single beam UV-Vis spectrophotometer (Agilent) both prior to and post irradiation at room temperature using Milli-Q water as the absorbance blank. Absorbance offsets $(O)$ were determined by averaging raw absorbance spectra over the $700-800 \mathrm{~nm}$ range and were subsequently subtracted from absorbance spectra. All corrected absorbance $\left(A_{\text {corr }}=A-O\right)$ were then converted to Napierian absorption coefficients $\left[a_{\mathrm{g}}(\lambda)\right.$; $\mathrm{m}^{-1}$ ] with the equation:

$$
a_{\mathrm{g}}(\lambda)=2.303 A_{\mathrm{corr}}(\lambda) / L
$$

over the $250-700 \mathrm{~nm}$ range, where $L(\mathrm{~m})$ is the pathlength of the spectrophotometric or waveguide cell.

The photon dose absorbed by CDOM for each wavelength interval over the course of an experiment was calculated using the following equation (Hu et al., 2002):

$$
Q_{a}(\lambda)=E_{0}(\lambda)\left(a_{\mathrm{g}}(\lambda) / a_{\mathrm{t}}(\lambda)\right) S\left[1-\exp \left(-a_{\mathrm{t}}(\lambda) L\right)\right]
$$

where $Q_{a}$ is the mol photons absorbed $s^{-1}$ by the sample, $\lambda$ is wavelength $(\mathrm{nm}), E_{0}$ is irradiance entering the top of the cell (mols photons $\mathrm{m}^{-2} \mathrm{~s}^{-1}$ ), $S$ is the irradiated surface area of the spectrophotometric cell $\left(\mathrm{m}^{2}\right), a_{\mathrm{g}}$ and $a_{\mathrm{t}}$ are the absorption coefficients for CDOM and for the total solution respectively $\left(\mathrm{m}^{-1}\right)$, and $L$ is the pathlength of the spectrophotometric cell $(\mathrm{m})$. The experimental photochemical production under each cutoff filter is defined according to the equation:

$$
\mathrm{dP} / \mathrm{dt}=\mathrm{AQY} \times Q_{\mathrm{a}}
$$

where the $\mathrm{dP} / \mathrm{dt}$ is the measured production rate of the species in question $\left(\mathrm{H}_{2} \mathrm{O}_{2}\right.$ here $)$ per experiment. The intentional variation of $Q_{a}$ using multiple irradiation spectra gives production results that allow use of an in-house MATLAB ${ }^{\circledR}$ routine for iterative, non-linear fitting to solve for the single AQY spectrum that best describes the production measured under all of the cutoff filters for a single experiment with the following equation (Ziolkowski and Miller, 2007; Xie et al., 2009; White et al., 2010; Powers and Miller, 2015b):

$$
\left.\Phi(\lambda)=\exp \left(-m_{1}+m_{2}(\lambda-290)\right)\right)
$$

where $m_{1}$ and $m_{2}$ are fitting parameters and 290 is a reference wavelength $(\mathrm{nm})$. The statistical robustness of the determined AQY spectrum was analyzed using the $r^{2}$ of a linear regression between measured $\left[\mathrm{H}_{2} \mathrm{O}_{2}\right]$ in each sample cell vs. that predicted for each cell by the resulting AQY spectrum and spectral photon dose using Equation (3) (integrated from 280 to $600 \mathrm{~nm}$ ) and by calculating the normalized root mean square error (nRMSE) between the two.

\section{RESULTS}

\section{Optimizing Irradiation Conditions for AQY Experiments}

Using $\mathrm{H}_{2} \mathrm{O}_{2}$ measurements to provide $\mathrm{O}_{2}^{-}$production rates for use in AQY calculations requires a known $\mathrm{O}_{2}^{-}: \mathrm{H}_{2} \mathrm{O}_{2}$ reaction stoichiometry as discussed above. Like Petasne and Zika (1987), we used SOD to kinetically force the well-known 2:1 dismutation reaction described by Bielski et al. (1985). To ensure that all photochemically generated $\mathrm{O}_{2}^{-}$in our samples was catalyzed by $\mathrm{SOD}$ via the disproportionation reaction to $\mathrm{H}_{2} \mathrm{O}_{2}$, we measured photochemical $\mathrm{H}_{2} \mathrm{O}_{2}$ generation with a range of added SOD concentrations (Figure 1). SRE water, potentially containing higher levels of possible reactants with $\mathrm{O}_{2}^{-}$, was used to determine the concentration of SOD needed to kinetically outcompete all other possible reactions with $\mathrm{O}_{2}^{-}$and ensure the 2:1 dismutation stoichiometry during a $15-$ min irradiation. An asymptote for $\mathrm{H}_{2} \mathrm{O}_{2}$ production was noted in our SOD addition series, indicating that $3.0 \times 10^{3}$ Units $\mathrm{L}^{-1}$ is all that it takes to ensure maximal $\mathrm{H}_{2} \mathrm{O}_{2}$ production. Consequently, we chose to add $1.5 \times 10^{4}$ Units $\mathrm{L}^{-1}$ SOD $(5 \times$ this activity) to each sample in all subsequent irradiation experiments containing SOD.

It is also essential that SOD is not denatured, and maintains its activity for the duration of its exposure to sunlight. Previous tests performed during our work in the Gulf of Alaska (Powers et al., 2015) using SOD with direct $\mathrm{O}_{2}^{-}$measurements confirmed that SOD is not deactivated by extended exposure to maximum output of the Suntest CPS solar simulator, exhibiting about $3 \times$ the photon flux used in the AQY experiments performed here. Seawater in water jacketed beakers with quartz covers containing added SOD of the activity levels shown in Figure 1 showed no measurable $\mathrm{O}_{2}^{-}$production throughout $60 \mathrm{~min}$ of constant exposure (Powers and Miller, 2014; Powers et al., 2015), indicating that SOD catalyzed dismutation continues at maximal rates in extended, full sun exposure. Consequently, results from our SOD-added experiments are assumed to represent $\mathrm{H}_{2} \mathrm{O}_{2}$ production exclusively via the SOD catalyzed disproportionation reaction.

One last critical issue for any accurate AQY calculation made using a single time point measurement is the assumption that photochemical production is linear to the point at which the sample is sacrificed and measured. As noted previously, $\mathrm{H}_{2} \mathrm{O}_{2}$ photochemical efficiency decreases with prolonged exposure 


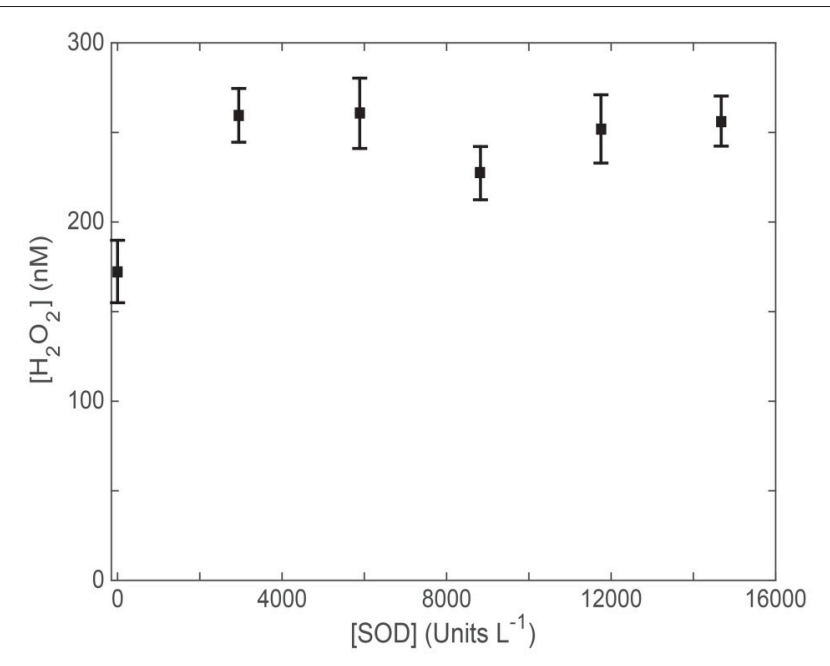

FIGURE 1 | $\mathrm{H}_{2} \mathrm{O}_{2}$ (nM) generation during a 15 min irradiation of Skidaway River Estuarine (SRE) water with various concentrations of added superoxide dismutase (SOD; Units $\mathrm{L}^{-1}$ based on the manufacturer's assay).

(Kieber et al., 2014; Powers and Miller, 2015a). Therefore, to ensure $\mathrm{H}_{2} \mathrm{O}_{2}$ photoproduction was always a linear function of photon dose during our AQY experiments, we performed broadband irradiation of SRE water and plotted the resulting data against $Q_{\mathrm{a}}(\lambda)$ integrated from 280 to $600 \mathrm{~nm}$ (mol photons absorbed) at each time point over the course of the irradiation (Figure 2). After $\sim 2 \mathrm{~h}$ of irradiation, amounting to a photon dose of $0.15 \mathrm{mmol}$ photons absorbed, $\mathrm{H}_{2} \mathrm{O}_{2}$ photoproduction slowed. Therefore, for all seawater irradiations used in AQY determinations in this study, we limited sample photon doses to $0.15 \mathrm{mmol}$ photons absorbed or less.

\section{$\mathrm{H}_{2} \mathrm{O}_{2}$ Apparent Quantum Yield Spectra}

Laboratory determined AQY spectra for all SAB seawater samples decreased monotonically from low UV to visible wavelengths and fell within a relatively narrow range (Figure 3; Table 1A). $\mathrm{H}_{2} \mathrm{O}_{2}$ AQY spectra for samples with no SOD treatment ranged from between 2.9 and $4.2 \times 10^{-4}$ (mol $\mathrm{H}_{2} \mathrm{O}_{2} / \mathrm{mol}$ photons absorbed) at $300 \mathrm{~nm}$ to between 0.24 and $0.37 \times 10^{-4}\left(\mathrm{~mol} \mathrm{H} \mathrm{O}_{2} / \mathrm{mol}\right.$ photons absorbed) at $400 \mathrm{~nm}$. The Altamaha River sample had the highest photochemical efficiency, with AQY values of $10 \times 10^{-4}\left(\mathrm{~mol} \mathrm{H} \mathrm{H}_{2} \mathrm{O}_{2} / \mathrm{mol}\right.$ photons absorbed) and $1.0 \times 10^{-4}\left(\mathrm{~mol} \mathrm{H}_{2} \mathrm{O}_{2} / \mathrm{mol}\right.$ photons absorbed) at $300 \mathrm{~nm}$ and $400 \mathrm{~nm}$, respectively. With added $\mathrm{SOD}$, the magnitude of the $\mathrm{H}_{2} \mathrm{O}_{2}$ AQY spectrum for all samples (riverine to Gulf Stream waters) increased in the UVB and to a lesser extent, in the UVA, resulting in higher slope coefficients ( $m_{2}$ values, Table 1$)$. This increase was largest for Gulf Stream waters and lowest for the Altamaha River sample. The AQY spectrum determined for each sample was also used to predict photoproduced $\mathrm{H}_{2} \mathrm{O}_{2}$ in each sample cell (i.e., all light treatments). The resulting measured vs. predicted $\mathrm{H}_{2} \mathrm{O}_{2}$ correlations had $r^{2} \geq 0.95$ and normalized root mean square

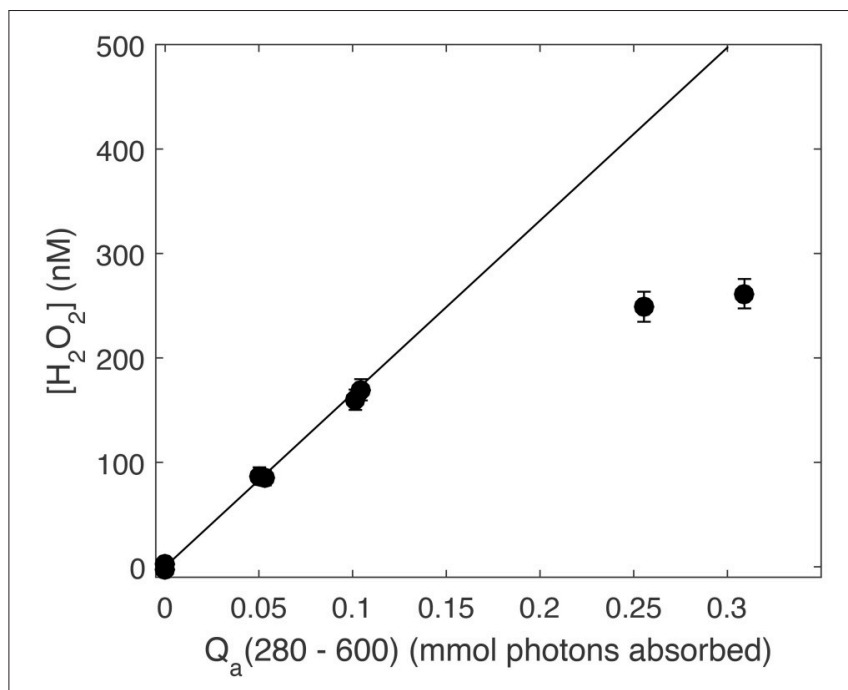

FIGURE 2 | Photoproduced $\mathrm{H}_{2} \mathrm{O}_{2}$ (nM) vs. absorbed photon dose integrated from 280 to $600 \mathrm{~nm}\left(\mathrm{Q}_{\mathrm{a}}, \mathbf{m m o l}\right.$ photons absorbed). The solid line represents the linear production rate over the first hour of irradiation (absorbed photon dose of $\sim 0.05 \mathrm{mmol}$ photons) using only $\mathrm{H}_{2} \mathrm{O}_{2}$ at the first time point.

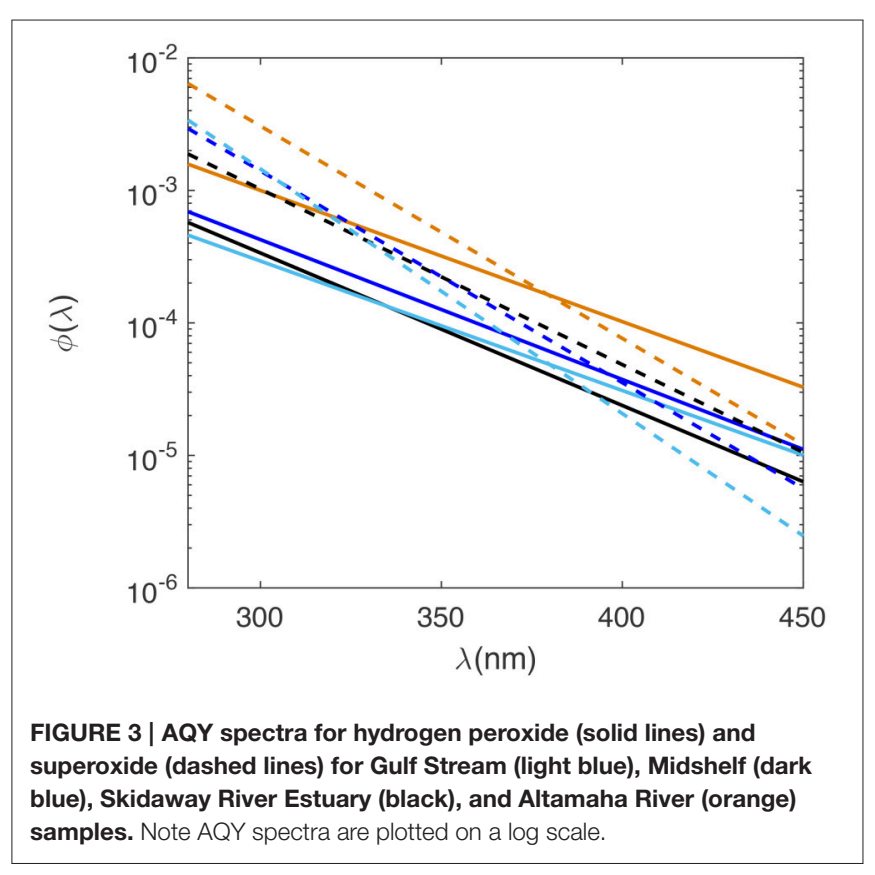

errors (nRMSE) $<8 \%$ for all but the untreated Gulf Stream sample $\left(r^{2}=0.91 ; \mathrm{nRMSE}=9.2 \%\right)$.

\section{Superoxide:Hydrogen Peroxide Ratios}

Superoxide photoproduction rates were determined by assuming that the 2:1 dispropotionation stoichiometry is valid in the presence of added SOD and the $\mathrm{O}_{2}^{-}$production rates are double those required to produce observed $\mathrm{H}_{2} \mathrm{O}_{2}$ (i.e., $\mathrm{O}_{2}^{-}=2 \times \mathrm{H}_{2} \mathrm{O}_{2}$ ). AQY spectra for $\mathrm{O}_{2}^{-}$were then determined by repeating the non-linear curve fitting routine using $2 \times$ the $\mathrm{H}_{2} \mathrm{O}_{2}$ data for 
TABLE $2 \mid \mathrm{O}_{2}^{-}: \mathrm{H}_{2} \mathrm{O}_{2}$ ratios measured directly (under either the $\mathbf{2 8 0}$ or $\mathbf{3 0 5}$ $n m$ cutoff filters, $n=2$ ) or from all $A Q Y$ experimental data and the slope of the regression of $\mathrm{H}_{2} \mathrm{O}_{2}$ generated without SOD vs. that with SOD (Ratio = 2 divided by the slope; regressions shown in Figure 4).

\begin{tabular}{lccccc}
\hline Sample & $\mathbf{2 8 0} \mathbf{n m}$ cutoff & $\mathbf{3 0 5} \mathbf{n m}$ cutoff & Slope & All AQY data & $\boldsymbol{r}^{\mathbf{2}}$ \\
\hline Altamaha R. & $1.76 \pm 0.13$ & $1.92 \pm 0.04$ & $1.07 \pm 0.04$ & $1.87 \pm 0.08$ & 0.98 \\
SRE B & $2.76 \pm 0.22$ & $2.66 \pm 0.33$ & $0.71 \pm 0.03$ & $2.82 \pm 0.11$ & 0.99 \\
Midshelf & $2.56 \pm 0.10$ & $1.90 \pm 0.03$ & $0.79 \pm 0.07$ & $2.53 \pm 0.21$ & 0.94 \\
Gulf Stream & $3.23 \pm 1.18$ & $2.53 \pm 0.40$ & $0.59 \pm 0.11$ & $3.38 \pm 0.61$ & 0.77
\end{tabular}

The $r^{2}$ values of the regression are also listed.

each sample cell containing added SOD and their respective $Q_{a}(\lambda)$ spectra (Table 1B). Ratios of $\mathrm{O}_{2}^{-}$to $\mathrm{H}_{2} \mathrm{O}_{2}$ photoproduction were then determined in two ways: a broadband estimate and an AQY estimate with both listed in Table 2. The broadband estimate was determined as the average ratio between $2 \times$ $\mathrm{H}_{2} \mathrm{O}_{2}$ generated with added SOD to $\mathrm{H}_{2} \mathrm{O}_{2}$ generated with no treatment for samples under the 280 and $305 \mathrm{~nm}$ cutoff filters. The AQY estimate was determined from the slope of $\mathrm{H}_{2} \mathrm{O}_{2}$ with no SOD treatment compared to that with added SOD for all spectral treatments during the AQY experiment (Figure 4). The $\mathrm{O}_{2}^{-}: \mathrm{H}_{2} \mathrm{O}_{2}$ ratio was then determined as two divided by the slope of these regressions. Because the addition of SOD increased the $\mathrm{H}_{2} \mathrm{O}_{2}$ AQY spectra most in the UVB (i.e., $<320$ $\mathrm{nm}), \mathrm{O}_{2}^{-}: \mathrm{H}_{2} \mathrm{O}_{2}$ ratios were always higher under 280 cutoff filters when compared to the ratio determined for samples under the $305 \mathrm{~nm}$ cutoff filters for all samples but the Altamaha River (Table 2). Linear regressions of $\mathrm{H}_{2} \mathrm{O}_{2}$ production with and without added SOD are shown in Figure 4. The slope coefficients for these regressions decrease with decreasing CDOM absorption [Table 2, $a_{\mathrm{g}}(325)$ values listed in Table 1] ranging from 0.59 for the Gulf Stream sample to 1.07 for the Altamaha River sample. Results indicate that reductive and oxidative sinks are comparable for the Altamaha sample but, for the Gulf Stream sample, about $\sim 40 \%$ of the superoxide generated does not lead to $\mathrm{H}_{2} \mathrm{O}_{2}$ formation.

\section{DISCUSSION}

\section{Trends in $\mathrm{H}_{2} \mathrm{O}_{2}$ Photoproduction in Riverine to Offshore Waters}

$\mathrm{H}_{2} \mathrm{O}_{2}$ AQY values fell in a narrow range for $\mathrm{SAB}$ seawater samples (i.e., from 1.7 to $2.3 \times 10^{-4}$ at $325 \mathrm{~nm}$ ) despite a much larger range in CDOM absorption coefficients $\left(0.24\right.$ to $6.5 \mathrm{~m}^{-1}$ at $325 \mathrm{~nm}$ ). Previous studies have found that the $\mathrm{H}_{2} \mathrm{O}_{2}$ AQY spectra were similar in various marine waters (Yocis et al., 2000; Kieber et al., 2014), suggesting that differences in AQY values between studies could be due to the large activation energy $\left(E_{a}\right)$ for this wavelength and temperature dependent photoproduct (average $\mathrm{E}_{a}$ from $17 \mathrm{~kJ} \mathrm{~mol}^{-1}$ at $290 \mathrm{~nm}$ to $32 \mathrm{~kJ} \mathrm{~mol}^{-1}$ at 400 nm; Kieber et al., 2014). In contrast, Powers and Miller (2014) found lower $\mathrm{H}_{2} \mathrm{O}_{2}$ AQY spectra in oligotrophic waters compared to coastal waters. Because linear accumulation of $\mathrm{H}_{2} \mathrm{O}_{2}$ was not confirmed in this study, differences in AQY spectra could reflect differences in irradiation time and a lack of reciprocity for $\mathrm{H}_{2} \mathrm{O}_{2}$.

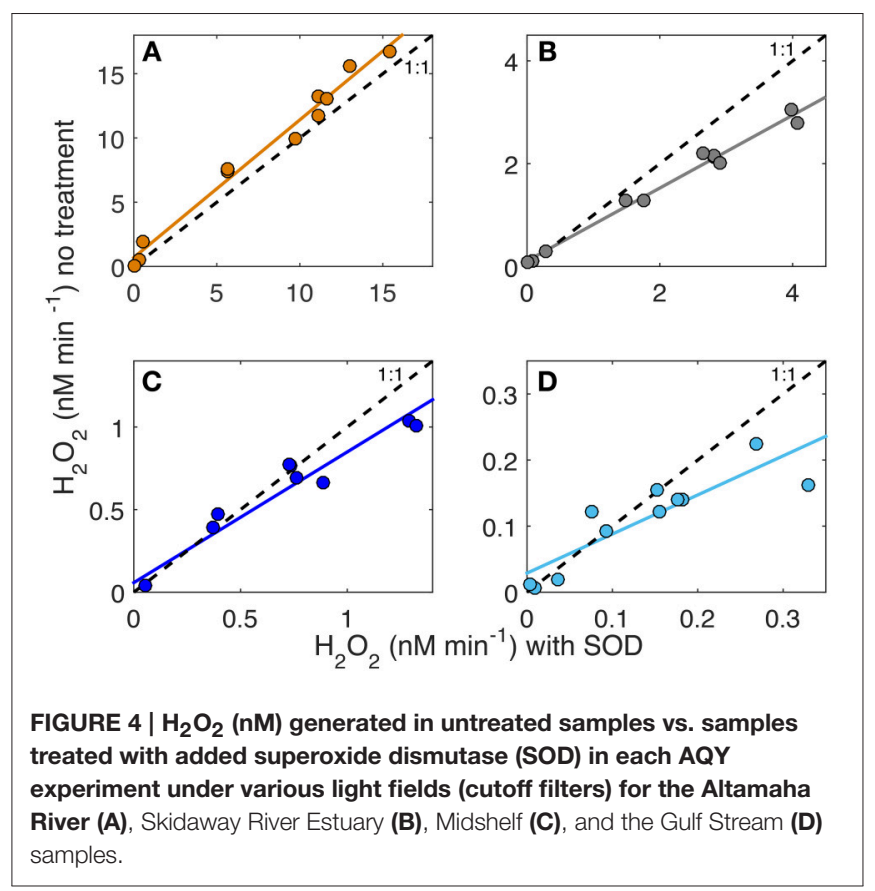

However, higher $\mathrm{H}_{2} \mathrm{O}_{2}$ photochemical efficiency has generally been observed in freshwaters (Cooper et al., 1988; Moore et al., 1993; O'Sullivan et al., 2005) when compared to both coastal and open ocean seawater (e.g., Yocis et al., 2000; Kieber et al., 2014; Powers and Miller, 2014).

In our study, the $\mathrm{H}_{2} \mathrm{O}_{2} \mathrm{AQY}$ for the Altamaha River was 5.4 \pm 0.7 times larger at $325 \mathrm{~nm}$ than all $\mathrm{SAB}$ seawater samples at the same wavelength, despite having $a_{\mathrm{g}}(325)$ values ranging from $\sim 2$ (SRE samples) to over 50 (Gulf stream) times larger (Table 1). The increased $\mathrm{H}_{2} \mathrm{O}_{2}$ AQY spectra for riverine water may reflect its terrestrial DOC source and a low exposure history. Zhang et al. (2014) demonstrated that the addition of phenol donors substantially increases the photoproduction of $\mathrm{H}_{2} \mathrm{O}_{2}$ from CDOM and Sharpless et al. (2014) have shown that prolonged irradiation tends to decrease CDOM electron donating capacity while having very little effect on electron accepting capacity. Perhaps the increased photoreactivity of the Altamaha River sample reflects an increased presence of phenolic compounds/electron donors, compared to seawater samples, even including the darker estuarine waters of the SRE. However, the reader is reminded that other factors in natural waters also impact $\mathrm{H}_{2} \mathrm{O}_{2}$ photoproduction efficiency including pH (Dalrymple et al., 2010) and metal chemistry (Shaked et al., 2010), as well as temperature (Kieber et al., 2014). Therefore, further mechanistic studies would be required to tease out the possible causes for variability in AQY spectra in various natural waters.

\section{Relating $\mathrm{H}_{2} \mathrm{O}_{2}$ Measurements to $\mathrm{O}_{2}^{-}$Data}

The best approach to evaluate superoxide photochemistry is to measure it directly. However, its instability in aqueous solutions creates a number of analytical limitations (Heller and Croot, 2010c), especially with regard to the determination 
of AQY spectra. Common methods to generate superoxide standards involve either UV-C generation of superoxide via a ketone/alcohol photolysis (McDowell et al., 1983; Rose et al., 2008; Powers et al., 2015) or additions of $\mathrm{KO}_{2}$ to alkaline solutions using trace metal clean techniques (Heller and Croot, 2010a,c; Diaz et al., 2013). Both methods generate $\mu \mathrm{M}$ concentrations of $\mathrm{O}_{2}^{-}$that allow direct monitoring via $\mathrm{UV}$ absorbance at $240 \mathrm{~nm}$. Superoxide from standards is added to seawater in nanomolar amounts but doesn't last very long and subsequent monitoring of superoxide decay, most commonly via flow injection analysis with chemiluminescent detection (FIACL; Burns et al., 2012), is required for calibration of the system. Measuring photochemical superoxide production in seawater samples is subject to similar analytical difficulties arising from $\mathrm{O}_{2}^{-}$ instability in seawater. FIA-CL requires precise and continuous pumping of the sample to a flow cell below the detector. Currently our irradiation system for AQY determinations does not facilitate direct measurement of $\mathrm{O}_{2}^{-}$from our individual, optically isolated, sealed spectrophotometric cells. Pumping samples would be limited to $30 \mathrm{ml}$ and create an unacceptable optical condition, introducing a changing gas volume that would create undefined changes in refraction and reflection. Thus, as a practical alternative to direct measurements of $\mathrm{O}_{2}^{-}$for deriving AQY spectra, we calculated $\mathrm{O}_{2}^{-}$from the analysis of $\mathrm{H}_{2} \mathrm{O}_{2}$ with SOD additions. The effective use of SOD in this way is supported by reports of its stability in $0.2 \mu \mathrm{m}$ filtered seawater (Petasne and Zika, 1987) and under solar radiation (Cooper and Zika, 1983; Draper and Crosby, 1983; Petasne and Zika, 1987) but it does lead to further consideration of both formation and decay mechanisms for superoxide in natural waters.

Previous work, using added phenol donors and borohydride reduction of CDOM prior to photochemical irradiations, has shown that the likely mechanism for superoxide photoproduction involves reaction of phenol electron donors with photo-excited triplet states of aromatic ketones within the DOM pool, generating ketyl radicals that react with $\mathrm{O}_{2}$ to form superoxide (Zhang et al., 2014, 2012). Additionally, Zhang et al. (2014) noted that the AQY for phenol loss was 2- to 10-fold higher than that observed for $\mathrm{H}_{2} \mathrm{O}_{2}$ production, consistent with superoxide formation rates greater than twice that for $\mathrm{H}_{2} \mathrm{O}_{2}$. In other words, their results are consistent with dominant superoxide decay involving oxidative pathways in the Suwannee River Fulvic and Humic Acid (SRFA and SRHA, respectively) solutions studied. A recent study by Zhang and Blough (2016) determined photoproduction rates of reducing intermediates using a nitroxyl radical probe to estimate the production rates of superoxide in SRFA and SRHA solutions. They observed production rates of reducing intermediates that were 13 times greater than those for $\mathrm{H}_{2} \mathrm{O}_{2}$ during polychromatic irradiations, similar to irradiation conditions in our study. Their results suggest that up to $67 \%$ of $\mathrm{O}_{2}^{-}$decays via oxidative pathways in these samples. Interestingly, we observed changes in the $\mathrm{H}_{2} \mathrm{O}_{2}$ AQY spectral shape with added SOD that may suggest additional oxidative pathways. Samples in our study showed increased efficiency in the UVB $(<320 \mathrm{~nm})$ and often the UVA $(\sim 340-360$ $\mathrm{nm}$ ) portion of the AQY spectrum (Figure 3). Consequently, all $\mathrm{O}_{2}^{-}$AQY spectra calculated using SOD additions, had steeper slopes than those observed for $\mathrm{H}_{2} \mathrm{O}_{2}$ without SOD. Since SOD should not alter photochemical formation mechanisms for $\mathrm{O}_{2}^{-}$, this apparent increase in efficiency at low wavelengths could represent a situation where SOD effectively outcompetes a natural phototransient oxidative sink generated by low UV wavelengths. This explanation is, of course, highly speculative and may simply represent natural variability in our AQY data. It does, however, suggest the presence of potential transient pathways for $\mathrm{O}_{2}^{-}$generated by UV solar radiation. The formation of $\mathrm{O}_{2}^{-}$sinks during photochemical irradiation still requires further study because direct $\mathrm{O}_{2}^{-}$photoproduction measurements made to date have been determined from measured $\mathrm{O}_{2}^{-}$steady-state concentrations during irradiation and dark decay post irradiation (e.g., Powers and Miller, 2015a; Powers et al., 2015) and raises the question "Do measurements of dark decay capture the complete story for $\mathrm{O}_{2}^{-}$redox pathways in sunlit surface waters?"

One potential proxy for partitioning superoxide sinks could be CDOM absorbance. The literature contains positive correlations between CDOM absorption coefficients and pseudo-first order decay constants for $\mathrm{O}_{2}^{-}$in coastal waters (Goldstone and Voelker, 2000) and negative correlations between $\mathrm{H}_{2} \mathrm{O}_{2}$ quantum yields and the E2/E3 ratio (i.e., absorbance at $254 \mathrm{~nm}$ divided by that at $365 \mathrm{~nm}$ ) (Dalrymple et al., 2010). We could not verify the E2/E3 trend with our small sample size $\left(r^{2}=0.16\right)$ but did find a negative correlation between $\mathrm{O}_{2}^{-}: \mathrm{H}_{2} \mathrm{O}_{2}$ ratios and $a_{\mathrm{g}}(325)$ $\left(r^{2}=0.69\right)$, albeit largely biased by a small sample set and high CDOM absorbance for the Altamaha sample. This approach may be of limited use even though our preliminary data suggests that the proportional oxidative sink for superoxide in blue water $\left(\mathrm{O}_{2}^{-}: \mathrm{H}_{2} \mathrm{O}_{2}\right.$ ratio of 3.4) is far larger than coastal waters with higher CDOM. On the other hand, ratios reported for open ocean waters in the Gulf of Alaska (Powers et al., 2015) had a large range of $\mathrm{O}_{2}^{-}: \mathrm{H}_{2} \mathrm{O}_{2}$ ratios (2.2-9.8) in surface and mesopelagic (1000 m) waters despite low variability in CDOM absorption coefficients [ $a_{\mathrm{g}}(325)$ from 0.13 to $0.39 \mathrm{~m}^{-1}$ ]. Clearly, CDOM absorption should not be the only factor considered when estimating the relationship between $\mathrm{O}_{2}^{-}$and $\mathrm{H}_{2} \mathrm{O}_{2}$ photoproduction. Work by P. Croot's group (e.g., Heller and Croot, 2011, 2010a; Wuttig et al., 2013) has shown dominant pathways for $\mathrm{O}_{2}^{-}$decay to include copper (Southern Ocean), manganese, or CDOM (Tropical Atlantic). These factors and others (e.g., metal speciation, $\mathrm{pH}$, temperature), that contribute to $\mathrm{O}_{2}^{-}$photoproduction and its subsequent decay to either $\mathrm{O}_{2}$ or $\mathrm{H}_{2} \mathrm{O}_{2}$ require further study.

From a practical point of view, it will require more than one stoichiometry if $\mathrm{H}_{2} \mathrm{O}_{2}$ AQY data is to be used to infer $\mathrm{O}_{2}^{-}$photoproduction data for large-scale photochemical models, even in the blue waters that dominate the world's oceans. For now, we can only say with confidence that for the majority of the world's oceans, an oxidative sink for $\mathrm{O}_{2}^{-}$is likely the dominant pathway for superoxide decay. Based on our limited data, instead of assuming that the 2:1 stoichiometry predicted from $\mathrm{O}_{2}^{-}$ dismutation is the same as it ever was, a more reasonable estimate of open ocean $\mathrm{O}_{2}^{-}: \mathrm{H}_{2} \mathrm{O}_{2}$ stoichiometry is probably closer to 4:1. Previous calculations of $\mathrm{O}_{2}^{-}$photochemistry based on $\mathrm{H}_{2} \mathrm{O}_{2}$ measurements (or AQY data) that use a $2: 1 \mathrm{O}_{2}^{-}: \mathrm{H}_{2} \mathrm{O}_{2}$ stoichiometry probably are vast underestimates of true $\mathrm{O}_{2}^{-}$ 
photoproduction rates in the surface ocean. Until future work allows us to understand the specific relationship (or lack thereof) between $\mathrm{O}_{2}^{-}$reactions and $\mathrm{H}_{2} \mathrm{O}_{2}$ production, global estimates of $\mathrm{O}_{2}^{-}$from $\mathrm{H}_{2} \mathrm{O}_{2}$ remain highly uncertain. Until such time, measurements of $\mathrm{H}_{2} \mathrm{O}_{2}$ photoproduction in the presence of sufficient SOD represent a convenient way to predict $\mathrm{O}_{2}^{-}$AQY spectra. Here we report only four $\mathrm{O}_{2}^{-}$AQY spectra from a range of natural waters, but encourage further use of this approach to amass the data required to address the variability in $\mathrm{O}_{2}^{-}$ AQY spectra in blue waters that will support new and better global models of the photochemical redox chemistry driven by superoxide production.

\section{AUTHOR CONTRIBUTIONS}

LP and WM both contributed to the experimental design of the work. LP carried out the experiments and data analysis. LP

\section{REFERENCES}

Bielski, B. H. J. (1978). Reevaluation of the spectral and kinetic properties of $\mathrm{HO}_{2}$ and $\mathrm{O}_{2}^{-}$free radicals. Photochem. Photobiol. 28, 645-649. doi: 10.1111/j.17511097.1978.tb06986.x

Bielski, B. H. J., and Allen, A. O. (1977). Mechanism of the disproportionation of superoxide radicals. J. Phys. Chem. 81, 1048-1050. doi: 10.1021/j100526a005

Bielski, B. H. J., Cabelli, D. E., Arudi, R. L., and Ross, A. B. (1985). Reactivity of $\mathrm{HO}_{2} / \mathrm{O}_{2}^{-}$radicals in aqueous solution. J. Phys. Chem. Ref. Data 14, 1041-1100. doi: 10.1063/1.555739

Burns, J. M., Cooper, W. J., Ferry, J. L., King, D. W., DiMento, B. P., McNeill, K., et al. (2012). Methods for reactive oxygen species (ROS) detection in aqueous environments. Aquat. Sci. 74, 683-734. doi: 10.1007/s00027-0120251-x

Cooper, W. J., Lean, D. R. S., and Carey, J. H. (1989). Spatial and temporal patterns of hydrogen peroxide in lake waters. Can. J. Fish. Aquat. Sci. 46, 1227-1231. doi: 10.1139/f89-158

Cooper, W. J., and Zika, R. G. (1983). Photochemical formation of hydrogen peroxide in surface and ground waters exposed to sunlight. Science 220, 711-712. doi: 10.1126/science.220.4598.711

Cooper, W. J., Zlka, R., Petasne, R. G., and Plane, J. M. C. (1988). Photochemical formation of $\mathrm{H} 202$ in natural waters exposed to sunlight. Environ. Sci. Technol. 22, 1156-1160. doi: 10.1021/es00175a004

Cudd, A., and Fridovich, I. (1982). Electrostatic interactions in the reaction mechanism of bovine erythrocyte superoxide dismutase. J. Biol. Chem. 257, 11443-11447.

Dalrymple, R. M., Carfagno, A. K., and Sharpless, C. M. (2010). Correlations between dissolved organic matter optical properties and quantum yields of singlet oxygen and hydrogen peroxide. Environ. Sci. Technol. 44, 5824-5829. doi: 10.1021/es101005u

Diaz, J. M., Hansel, C. M., Voelker, B. M., Mendes, C. M., Andeer, P. F., and Zhang, T. (2013). Widespread production of extracellular superoxide by heterotrophic bacteria. Science 340, 1223-1226. doi: 10.1126/science.1237331

Draper, W. M., and Crosby, D. G. (1983). Photochemical generation of superoxide radical anion in water. J. Agric. Food Chem. 31, 734-737. doi: 10.1021/jf00118a014

Garg, S., Rose, A. L., and Waite, T. D. (2011). Photochemical production of superoxide and hydrogen peroxide from natural organic matter. Geochim. Cosmochim. Acta. 75, 4310-4320. doi: 10.1016/j.gca.2011.05.014

Goldstone, J. V., and Voelker, B. M. (2000). Chemistry of superoxide radical in seawater: CDOM associated sink of superoxide in coastal waters. Environ. Sci. Technol. 34, 1043-1048. doi: 10.1021/es9905445

Heller, M. I., and Croot, P. L. (2010a). Superoxide decay kinetics in the southern ocean. Environ. Sci. Technol. 44, 191-196. doi: 10.1021/es901766r and WM contributed equally to interpretation of the work and drafting this manuscript.

\section{FUNDING}

This work was supported by NSF grant OCE-1234388 awarded to WM.

\section{ACKNOWLEDGMENTS}

The authors would like to thank Courtney Bahrs and the captain and crew of the R/V Savannah for assistance with sample collection and in the laboratory. Some materials in this manuscript are based on work supported while WM was serving at the National Science Foundation.
Heller, M. I., and Croot, P. L. (2010b). Kinetics of superoxide reactions with dissolved organic matter in tropical Atlantic surface waters near Cape Verde (TENATSO). J. Geophys. Res. 115, C12038. doi: 10.1029/2009JC006021

Heller, M. I., and Croot, P. L. (2010c). Application of a superoxide $\left(\mathrm{O}_{2}^{-}\right)$ thermal source (SOTS-1) for the determination and calibration of $\mathrm{O}_{2}^{-}$ fluxes in seawater. Anal. Chim. Acta 667, 1-13. doi: 10.1016/j.aca.2010. 03.054

Heller, M. I., and Croot, P. L. (2011). Superoxide decay as a probe for speciation changes during dust dissolution in Tropical Atlantic surface waters near Cape Verde. Mar. Chem. 126, 37-55. doi: 10.1016/j.marchem.2011.03.006

Hu, C., Muller-karger, F. E., and Zepp, R. G. (2002). Absorbance, absorption coefficient, and apparent quantum yield: a comment on common ambiguity in the use of these optical concepts. Limnol. Oceanogr. 47, 1261-1267. doi: 10.4319/lo.2002.47.4.1261

Kieber, D. J., Miller, G. W., Neale, P. J., and Mopper, K. (2014). Wavelength and temperature-dependent apparent quantum yields for photochemical formation of hydrogen peroxide in seawater. Environ. Sci. Process. Impacts 16, 777-791. doi: 10.1039/c4em00036f

Kieber, D. J., Peake, B. M., and Scully, N. M. (2003). "Reactive oxygen species in aquatic ecosystems," in UV Effects in Aquatic Organisms and Ecosystems, eds E. W. Helbling and H. Zagarese (Cambridge, UK: Royal Chemistry Society), 251-288.

King, D. W., Cooper, W. J., Rusak, S. A., Peake, B. M., Kiddle, J. J., O’Sullivan, D. W., et al. (2007). Flow injection analysis of $\mathrm{H} 2 \mathrm{O} 2$ in natural waters using acridinium ester chemiluminescence: method development and optimization using a kinetic model. Anal. Chem. 79, 4169-4176. doi: 10.1021/ac062228w

McDowell, M. S., Bakac, A., and Espenson, J. H. (1983). A convenient route to superoxide ion in aqueous solution. Inorg. Chem. 22, 847-848. doi: 10.1021/ic00147a033

Miller, R. L., Belz, M., Castillo, C., and Del Trzaska, R. (2002). Determining CDOM absorption spectra in diverse coastal environments using a multiple pathlength, liquid core waveguide system. Cont. Shelf Res. 22, 1301-1310. doi: 10.1016/S0278-4343(02)00009-2

Miller, W. L., and Kester, D. R. (1988). Hydrogen peroxide measurement in seawater by (p-Hydroxyphenyl) acetic acid dimerization. Anal. Chem. 60, 2711-2715. doi: 10.1021/ac00175a014

Moore, C., Farmer, C., and Zika, R. (1993). Influence of the Orinoco River on hydrogen peroxide distribution and production in the Eastern Caribbean. J. Geophys. Res. 98, 2289-2298. doi: 10.1029/92JC02767

O'Sullivan, D. W., Neale, P. J., Coffin, R. B., Boyd, T. J., and Osburn, C. L. (2005). Photochemical production of hydrogen peroxide and methylhydroperoxide in coastal waters. Mar. Chem. 97, 14-33. doi: 10.1016/j.marchem.2005.04.003

Petasne, R. G., and Zika, R. G. (1987). Fate of superoxide in coastal seawater. Nature 325, 516-618. doi: 10.1038/325516a0 
Powers, L. C., Babcock-Adams, L. C., Enright, J. K., and Miller, W. L. (2015). Probing the photochemical reactivity of deep ocean refractory carbon (DORC): lessons from hydrogen peroxide and superoxide kinetics. Mar. Chem. 177, 306-317. doi: 10.1016/j.marchem.2015.06.005

Powers, L. C., and Miller, W. L. (2014). Blending remote sensing data products to estimate photochemical production of hydrogen peroxide and superoxide in the surface ocean. Environ. Sci. Process. Impacts 16, 792-806. doi: 10.1039/C3EM00617D

Powers, L. C., and Miller, W. L. (2015a). Hydrogen peroxide and superoxide photoproduction in diverse marine waters: a simple proxy for estimating direct $\mathrm{CO}_{2}$ photochemical fluxes. Geophys. Res. Lett. 42, 7696-7704. doi: $10.1002 / 2015$ GL065669

Powers, L. C., and Miller, W. L. (2015b). Photochemical production of CO and $\mathrm{CO}_{2}$ in the Northern Gulf of Mexico: estimates and challenges for quantifying the impact of photochemistry on carbon cycles. Mar. Chem. 171, 21-35. doi: 10.1016/j.marchem.2015.02.004

Rose, A. L., Moffett, J. W., and Waite, T. D. (2008). Determination of superoxide in seawater using 2-Methyl-6-(4-methoxyphenyl)-3,7-dihydroimidazo[1,2a]pyrazin-3(7H)-one chemiluminescence. Anal. Chem. 80, 1215-1227. doi: $10.1021 /$ ac7018975

Rose, A. L., and Waite, T. D. (2006). Role of superoxide in the photochemical reduction of iron in seawater. Geochim. Cosmochim. Acta 70, 3869-3882. doi: 10.1016/j.gca.2006.06.008

Rusak, S. A., Peake, B. M., Richard, L. E., Nodder, S. D., and Cooper, W. J. (2011). Distributions of hydrogen peroxide and superoxide in seawater east of New Zealand. Mar. Chem. 127, 155-169. doi: 10.1016/j.marchem.2011.08.005

Shaked, Y., Harris, R., and Klein-Kedem, N. (2010). Hydrogen peroxide photocycling in the Gulf of Aqaba, Red Sea. Environ. Sci. Technol. 44, 3238-3244. doi: 10.1021/es902343y

Sharpless, C. M., Aeschbacher, M., Page, S. E., Wenk, J., Sander, M., and McNeill, K. (2014). Photooxidation-induced changes in optical, electrochemical, and photochemical properties of humic substances. Environ. Sci. Technol. 48, 2688-2696. doi: 10.1021/es403925g

Stubbins, A., Uher, G., Law, C. S., Mopper, K., Robinson, C., and Upstill-Goddard, R. C. (2006). Open-ocean carbon monoxide photoproduction. Deep Sea Res. II Top. Stud. Oceanogr. 53, 1695-1705. doi: 10.1016/j.dsr2.2006.05.011

Szymczak, R., and Waite, T. D. (1988). Generation and decay of hydrogen peroxide in Estuarine Waters. Aust. J. Mar. Freshw. Res. 39, 289-299. doi: $10.1071 / \mathrm{mf} 9880289$

Voelker, B. M., Sedlak, D. L., and Zafiriou, O. C. (2000). Chemistry of Superoxide radical in seawater: reactions with organic $\mathrm{Cu}$ complexes. Environ. Sci. Technol. 34, 1036-1042. doi: 10.1021/es990545x
White, E. M., Kieber, D. J., Sherrard, J., Miller, W. L., and Mopper, K. (2010). Carbon dioxide and carbon monoxide photoproduction quantum yields in the Delaware Estuary. Mar. Chem. 118, 11-21. doi: 10.1016/j.marchem.2009. 10.001

Wuttig, K., Heller, M. I., and Croot, P. L. (2013). Pathways of superoxide $\left(\mathrm{O}_{2}^{-}\right)$ decay in the Eastern Tropical North Atlantic. Environ. Sci. Technol. 47, 10249-10256. doi: 10.1021/es401658t

Xie, H., Bélanger, S., Demers, S., Vincent, W. F., and Papakyriakou, T. N. (2009). Photobiogeochemical cycling of carbon monoxide in the southeastern Beaufort Sea in spring and autumn. Limnol. Oceanogr. 54, 234-249. doi: 10.4319/lo.2009.54.1.0234

Yocis, B. H., Kieber, D. J., and Mopper, K. (2000). Photochemical production of hydrogen peroxide in Antarctic Waters. Deep Sea Res. I Oceanogr. Res. Pap. 47, 1077-1099. doi: 10.1016/S0967-0637(99)00095-3

Zafiriou, O. C., Blough, N. V., Micinski, E., Dister, B., Kieber, D., and Moffett, J. (1990). Molecular probe systems for reactive transients in natural waters. Mar. Chem. 30, 45-70. doi: 10.1016/0304-4203(90)90061-G

Zhang, Y., and Blough, N. V. (2016). Photoproduction of one-electron reducing intermediates by chromophoric dissolved organic matter (CDOM): Relation to $\mathrm{O}_{2}$ - and $\mathrm{H}_{2} \mathrm{O}_{2}$ photoproduction and $\mathrm{CDOM}$ photooxidation. Enrivron. Sci. Technol. 50, 11008-11015. doi: 10.1021/acs.est.6b02919

Zhang, Y., Del Vecchio, R., and Blough, N. V. (2012). Investigating the mechanism of hydrogen peroxide photoproduction by humic substances. Environ. Sci. Technol. 46, 11836-11843. doi: 10.1021/es3029582

Zhang, Y., Simon, K. A., Andrew, A. A., Del Vecchio, R., and Blough, N. V. (2014), Enhanced photoproduction of hydrogen peroxide by humic substances in the presence of phenol electron donors. Environ. Sci. Technol. 48, 12679-12688. doi: $10.1021 /$ es5035798

Ziolkowski, L. A., and Miller, W. L. (2007). Variability of the apparent quantum efficiency of CO photoproduction in the Gulf of Maine and Northwest Atlantic. Mar. Chem. 105, 258-270. doi: 10.1016/j.marchem.2007.02.004

Conflict of Interest Statement: The authors declare that the research was conducted in the absence of any commercial or financial relationships that could be construed as a potential conflict of interest.

Copyright $\odot 2016$ Powers and Miller. This is an open-access article distributed under the terms of the Creative Commons Attribution License (CC BY). The use, distribution or reproduction in other forums is permitted, provided the original author(s) or licensor are credited and that the original publication in this journal is cited, in accordance with accepted academic practice. No use, distribution or reproduction is permitted which does not comply with these terms. 